\title{
Impact of the 1997-98 El Niño event on the coral reef-associated echinoderm assemblage from northern Bahia, northeastern Brazil
}

\author{
Martin J. Attrill ${ }^{1, *}$, Francisco Kelmo ${ }^{1,2}$, Malcolm B. Jones ${ }^{1}$ \\ ${ }^{1}$ School of Biological Sciences, University of Plymouth, Drake Circus, Plymouth PL4 8AA, UK \\ ${ }^{2}$ Brazilian Research Council-CNPq Brazil \& Departamento de Zoologia, Instituto de Biologia, Universidade Federal da \\ Bahia, Campus Universitário de Ondina, Salvador, Bahia, 40210-340, Brazil
}

\begin{abstract}
The 1997-98 El Niño event was the most severe on record, resulting in record elevated water temperatures across much of the world's tropical ocean regions. This event triggered extensive bleaching of coral reefs world-wide, but little information is available on the impact of this major global event on the non-coral invertebrates associated with reef systems. Here, we report the results of a 6 yr (1995-2000) survey of the echinoderm assemblage from 4 coral reef systems in Bahia, Brazil; the 1997-98 El Niño event occurred in the middle of the survey, allowing impact and recovery to be assessed. At each location, 3 contrasting reef habitats were sampled (intertidal emergent reef tops, coastal reef walls, offshore shallow-bank reefs), with all echinoderm species being identified and enumerated. The El Niño event had a dramatic and consistent impact on the echinoderm assemblage, with a sharp post-El Niño decrease in the number of species from all habitats. However, declines in diversity continued into subsequent years, with the local extinction of the majority of echinoderm species by 2000. In contrast, echinoderm density peaked in 1998, due to opportunistic increases in urchin populations (Diadema antillarum and Echinometra lacunter) across the studied reef systems. Multivariate analysis confirmed a marked change in echinoderm assemblage composition between 1997 and 1998 for all reef habitats, with no evidence of recovery to a pre-El Niño assemblage in the 2 subsequent years. The stresses associated with the El Niño event, in the case of Bahia increases in water temperature and ultraviolet light reaching the reef (reduced cloud cover and turbidity), appear to have had a lethal impact on the majority of reef echinoderm species with no evidence of recovery over 2 yr following El Niño. Increases in urchins are most likely due to migration of individuals onto the reef from deeper areas to exploit the reduced competition and potential increasing algal food resource. The study highlights that El Niño can have severe impacts on reef systems additional to the effect on corals.
\end{abstract}

KEY WORDS: El Niño/Southern Oscillation $\cdot$ ENSO $\cdot$ Echinodermata $\cdot$ Diadema $\cdot$ Echinometra Community $\cdot$ Local extinction

Resale or republication not permitted without written consent of the publisher

\section{INTRODUCTION}

The El-Niño event of 1997-8 was the most severe on record (McPhaden 1999a, Eakin 2001), triggering record high global seawater temperatures (McPhaden 1999b, Elliot et al 2001, Pezzi \& Cavalcanti 2001). These high temperatures resulted in large-scale coral bleaching (Berkelmans \& Oliver 1999, Linden 1999,
Glynn et al. 2001), with subsequent mass mortality of corals in most tropical ocean regions (e.g. Kelmo \& Attrill 2001, Aronson et al. 2002, Kayanne et al. 2002). Reports of the impact of the 1997-98 El Niño have concentrated mainly on the coral species themselves (e.g. Feingold 2001, Glynn et al. 2001) and the subsequent relationship with algal cover (McClanahan et al. 2001, Aronson et al. 2002). Studies on the fish community 
have been equivocal; no great changes in fish assemblage were noted in the Seychelles (Spalding \& Jarvis 2002), but marked changes in recruitment and abundance were recorded for the Great Barrier Reef (Booth \& Beretta 2002) and Tanzania (Lindahl et al. 2001). Limited information is available, however, for the impact of such a major global climatic event on the invertebrates associated with coral reefs. Kelmo et al. (2003, 2004) reported significant decreases in density and diversity of non-coral cnidarians and bryozoans in Bahia (Brazil), but data available on other invertebrate responses appear limited to changes in abundance of a few key grazing species of urchin (Haley \& Solandt 2001, McClanahan et al. 2001, Aronson et al. 2002).

Although echinoderms form a conspicuous group of the marine benthos throughout the coral reefs of Brazil, very little is known about the phylum as a whole. Most studies carried out on the Bahian coast have concentrated solely on the fauna from single reef systems (Tommasi \& Aron 1988, Albuquerque \& Guile 1991), and recently Alves \& Cerqueira (2000) published a list of species for regions close to Salvador (Bahia). Cerqueira (1995) and Santa-Isabel et al. (1996) reported aspects of the ecology of the group in Bahia (these studies were not carried out on coral reefs), but many aspects of the biology and ecology of the Brazilian coral-reef echinoderms remain unknown. To address this gap in knowledge, a long-term assessment programme of the echinoderm communities from the northern Bahia coral reefs was started in 1995. The primary aim was to quantify temporal and spatial patterns of biodiversity and community structure from 3 reef sub-habitats with contrasting environmental conditions and fauna (emergent reef tops, coastal reef walls, offshore shallow-bank reefs) at 4 locations. However, as the investigation encompassed the 1997 98 El Niño event, our results provide an unparalleled opportunity to assess the impact of this phase of El Niño/Southern Oscillation (ENSO) on the echinoderms associated with coral reefs in Bahia.

\section{MATERIALS AND METHODS}

\subsection{Study area}

Two types of coral reef occur in northern Bahia $\left(12^{\circ}\right.$ $\left.32^{\prime} 80^{\prime \prime} \mathrm{S}, 12^{\circ} 38^{\prime} 23^{\prime \prime} \mathrm{W}\right)$. Coastal emergent reefs are adjacent to the beaches, whereas shallow-bank reefs are found a few kilometres offshore. A small river (Pojuca) discharges in the proximity of these reefs, supplementing the sedimentary load from the 2 major rivers in the area, the São Francisco (ca. $200 \mathrm{~km}$ north of the reefs) and the Doce (ca. $180 \mathrm{~km}$ south of the reefs). The Bahian reef fauna has, therefore, evolved in naturally turbid conditions, with additional influence from extensive lowering of sea level during the last $3000 \mathrm{yr}$ (Martin \& Suguio 1992). Additionally, this area of Brazil has been isolated from the Caribbean by the Amazon barrier, the Amazon changing direction due to uplift of the Andes around 10 Myr (million yr) ago (Boeger \& Kritsky 2002) and, consequently, the coral reefs of Bahia contain a high proportion of endemic taxa (Kelmo et al. 2003). There are no seasonal rainfall patterns in this area, and only a $5^{\circ} \mathrm{C}$ range between summer and winter temperatures (see Kelmo et al. 2003 for a full description of the study area and climatic conditions).

\subsection{Sampling}

From 1995 to 2000, the echinoderm community from 4 separate reefs of northern Bahia was sampled annually (April/May) by SCUBA diving. Three reef habitats were sampled at each location: (1) the emergent tops of coastal reefs (exposed at low tide, with many pools), (2) the subtidal walls of coastal reefs and (3) subtidal shallow-bank reefs (offshore). In each reef habitat, quantitative samples were taken using 35 quadrats $\left(1 \mathrm{~m}^{2}\right)$, positioned randomly (i.e. different quadrat positions at each sample location, not fixed quadrats repeatedly sampled). In each quadrat, echinoderms were counted and identified in situ. Voucher specimens, collected each year, are stored at the scientific collection of the Department of Zoology, Federal University of Bahia, Salvador (UFBA).

Large-scale environmental parameters for stations adjacent to the survey area (sea-surface temperature, solar irradiance, air temperature, rainfall and cloud cover) were obtained from the Brazilian Meteorological Institute (INMET), Brasilia. INMET data are collected 3 times a day and the values presented in this paper represent the annual average of these data. INMET data are classified internationally in ISO9001. Local physico-chemical data (seawater temperature, salinity, pH and turbidity [subtidal sites only]) were recorded from each location (10 replicates reef ${ }^{-1}$, giving 40 measurements for each reef habitat spread across the sampling period).

\subsection{Data analysis}

As previous analyses demonstrated no difference between the 4 locations (Kelmo \& Attrill 2001), data for each site (i.e. reef type at each location) were pooled to assess temporal trends. Therefore, for each year in the single-factor analysis there were 4 replicates relating to the pooled data from each reef type. Environmental 

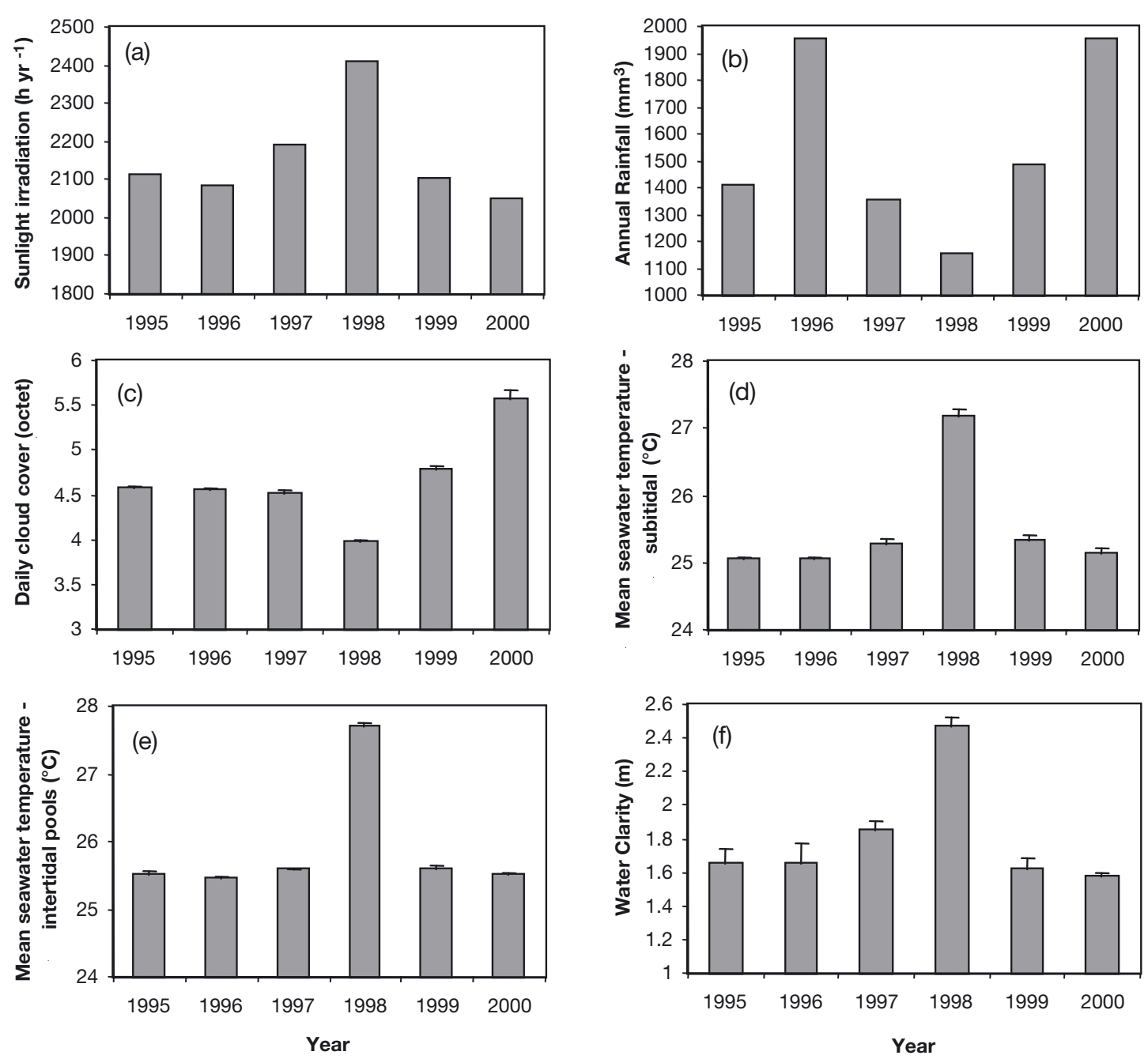

Fig. 1. Histograms of key environmental variables measured during each year of 1995-2000 for the Bahian reef region, demonstrating changes in ambient conditions during the El Niño period (1998). (a) Annual sunlight irradiance, (b) annual rainfall, (c) mean daily cloud cover (sample period) as number of octets of the sky covered by cloud, (d) mean subtidal seawater temperature (daily, sample period), (e) mean intertidal pool water temperature (daily, sample period), (f) mean water clarity measured using a Secchi disk (daily, sample period). Error bars indicate SE around the mean between replicate reef systems; sample period of 1 mo during April/May

parameters, and echinoderm density and species number data, were normalised and $\log (x+1)$-transformed where necessary (Cochran's test), and ANOVA or a Kruskall-Wallis test (non-normal environmental data - no transformation) used to assess differences between pre- and post-El Niño periods. A triangular matrix of similarities between echinoderm samples was constructed using the Bray-Curtis similarity index. The similarity matrix was subjected to clustering and ordination analyses using the program PRIMER (Plymouth Routines in Multivariate Ecological Research; Carr 1996). Clustering was by a hierarchical agglomerative method using group-average linking. Ordination was by non-metric multidimensional scaling (MDS). To verify the significance of differences in community composition between years, the ANOSIM test (Clarke \& Green 1988) was used. The contribution of species to dissimilarities between the groupings observed in the cluster and ordination analyses was examined using the SIMPER procedure ('similarity percentages'; Clarke 1993).

\section{RESULTS}

\subsection{Environmental parameters}

Pre-1998, environmental conditions were remarkably constant; however, the El Niño event had a significant influence on most of the measured parameters (Fig. 1; Kelmo et al. 2004). Mean air and seawater temperatures and hours of sunlight were elevated signifi- 
cantly in 1998 (post-hoc Student-Newman-Kuels test, Fig. 1a, d, e) compared with all other years, the latter due to lower cloud cover (Fig. 1c). Rainfall was significantly lower in 1998 (Fig. 1b), resulting in reduced sediment outflow from the local rivers (the mean annual discharge of the São Francisco River reduced from 32980 to $1768 \mathrm{~m}^{3} \mathrm{~s}^{-1}$ and that of the Doce River from
80.5 to $50.2 \mathrm{~m}^{3} \mathrm{~s}^{-1}$ ) and significantly clearer water (Fig. 1f).

In summary, environmental conditions in the Bahian reefs during 1998 were warmer than previously, with reduced cloud cover, increased insolation and reduced turbidity, resulting in more sunlight (and thus ultraviolet light) reaching the coral reefs. All environmental parameters returned to pre-El Niño values after 1998 (Fig. 1).

Table 1. Similarity percentages (SIMPER) analysis. Species of echinoderm contributing most to the dissimilarity between the 2 clusters: post-El Niño years (i.e. those after and including 1998) and pre-El Niño years (before 1998). Average densities $\left(\mathrm{m}^{-2}\right)$ for each period are displayed, together with the percentage contribution of each species to dissimilarities. Species are in rank order of highest contribution within each reef habitat; those contributing least show little change in density following El Niño

\begin{tabular}{|c|c|c|c|}
\hline \multirow[t]{2}{*}{ Species } & \multicolumn{2}{|c|}{ Average density } & \multirow{2}{*}{$\begin{array}{l}\text { Contribution to } \\
\text { dissimilarities (\% }\end{array}$} \\
\hline & Pre-El Niño & Post-El Niño & \\
\hline \multicolumn{4}{|l|}{ Emergent reef tops } \\
\hline Ophioderma cinereum & 0.22 & 0.00 & 22.26 \\
\hline Linckia guildingi & 0.26 & 0.01 & 20.15 \\
\hline Echinaster echinophorus & 0.17 & 0.01 & 18.31 \\
\hline Lithechinus variegatus & 0.09 & 0.00 & 18.24 \\
\hline Ophiocoma wendtii & 0.06 & 0.00 & 13.33 \\
\hline Echinometra lucunter & 6.91 & 9.41 & 7.72 \\
\hline \multicolumn{4}{|l|}{ Coastal reef walls } \\
\hline Lithechinus variegatus & 0.47 & 0.03 & 14.82 \\
\hline Encope emarginata & 0.36 & 0.03 & 13.70 \\
\hline Tropiometra carinata & 1.01 & 0.11 & 13.24 \\
\hline Ophionereis reticulata & 0.24 & 0.00 & 11.93 \\
\hline Linckia guildingi & 0.26 & 0.03 & 11.24 \\
\hline Echinaster echinophorus & 0.08 & 0.00 & 10.16 \\
\hline Ophiocnida scrabiuscula & 0.06 & 0.00 & 9.58 \\
\hline Ophioderma apressa & 0.05 & 0.00 & 8.05 \\
\hline Diadema antillarum & 5.63 & 9.16 & 4.73 \\
\hline Echinometra lucunter & 2.10 & 1.87 & 2.55 \\
\hline \multicolumn{4}{|l|}{ Shallow bank reefs } \\
\hline Lithechinus variegatus & 0.49 & 0.02 & 7.67 \\
\hline Ophiotrix angulata & 0.10 & 0.00 & 5.87 \\
\hline Tropiometra carinata & 0.35 & 0.07 & 5.69 \\
\hline Ophiocnida scrabiuscula & 0.07 & 0.00 & 5.37 \\
\hline Stichopus badionotus & 0.06 & 0.00 & 5.24 \\
\hline Linckia guildingi & 0.12 & 0.01 & 5.14 \\
\hline Ophiactis savigny & 0.06 & 0.00 & 5.10 \\
\hline Ophiomyxa flaccida & 0.06 & 0.00 & 5.08 \\
\hline Oreaster reticulatus & 0.06 & 0.00 & 4.80 \\
\hline Amphiura stimpsoni & 0.05 & 0.00 & 4.59 \\
\hline Ophioderma cinereum & 0.09 & 0.01 & 4.44 \\
\hline Ophionereis reticulata & 0.07 & 0.01 & 4.42 \\
\hline Ophioderma apressa & 0.09 & 0.01 & 4.39 \\
\hline Ophiocoma echinata & 0.07 & 0.01 & 4.31 \\
\hline Clypeaster roseaceus & 0.04 & 0.00 & 4.28 \\
\hline Encope emarginata & 0.07 & 0.01 & 4.28 \\
\hline Lovenia cordiformis & 0.03 & 0.00 & 3.91 \\
\hline Sclerodactyla briareus & 0.06 & 0.01 & 3.55 \\
\hline Eucidaris tribuloides & 0.81 & 0.22 & 2.93 \\
\hline Echinaster echinophorus & 0.22 & 0.04 & 2.60 \\
\hline Ophiocoma wendtii & 0.02 & 0.00 & 2.47 \\
\hline Diadema antillarum & 6.08 & 8.70 & 1.75 \\
\hline Echinometra lucunter & 2.30 & 2.13 & 1.24 \\
\hline Tripneustis ventricosus & 0.07 & 0.03 & 0.89 \\
\hline
\end{tabular}

\subsection{Echinoderm community}

A total of 24 species was recorded from the 3 contrasting reef habitats of northern Bahia (Table 1), including 3 asteroid species, 8 species of echinoid, 10 species of ophiuroid, 1 crinoid species and 2 species of holothuroid. Total echinoderm density demonstrated a significant trend for the 3 reef habitats (ANOVA all $\mathrm{p}<0.0001$; Fig. 2), with density peaking during the survey directly after the El Niño event (1998); for all habitats, a pre-El Niño increase was also evident. However, these patterns resulted from increases in numbers of the urchins Diadema antillarum (subtidal habitats) and Echinometra lucunter (reef tops). All other echinoderm species showed significant reductions in density 1 yr after El Niño (Table 1).

Although trends in number of echinoderm species were consistent across reef habitats, they were markedly different from the density trends (Fig. 3). A significant reduction (ANOVA all $p<0.0001$ ) in diversity was evident decline in number of species continuing in 1999. By 2000, almost all species were locally extinct; exceptions were Echinaster echinophorea (Asteroidea) and Tripneustis ventricosus, D. antillarum, E. lucunter and Eucidaris tribuloides (Echinoidea).

Multivariate analysis of the echinoderm assemblage data demonstrated dramatic shifts in assemblage composition between 1997 and 1998, coincident with the El Niño event (Fig. 4) and consistent across all 3 reef habitats. Prior to 1998, assemblages were remarkably similar across reefs and years, all 1995-97 sites clustering together in the directly after El Niño (1998), this 

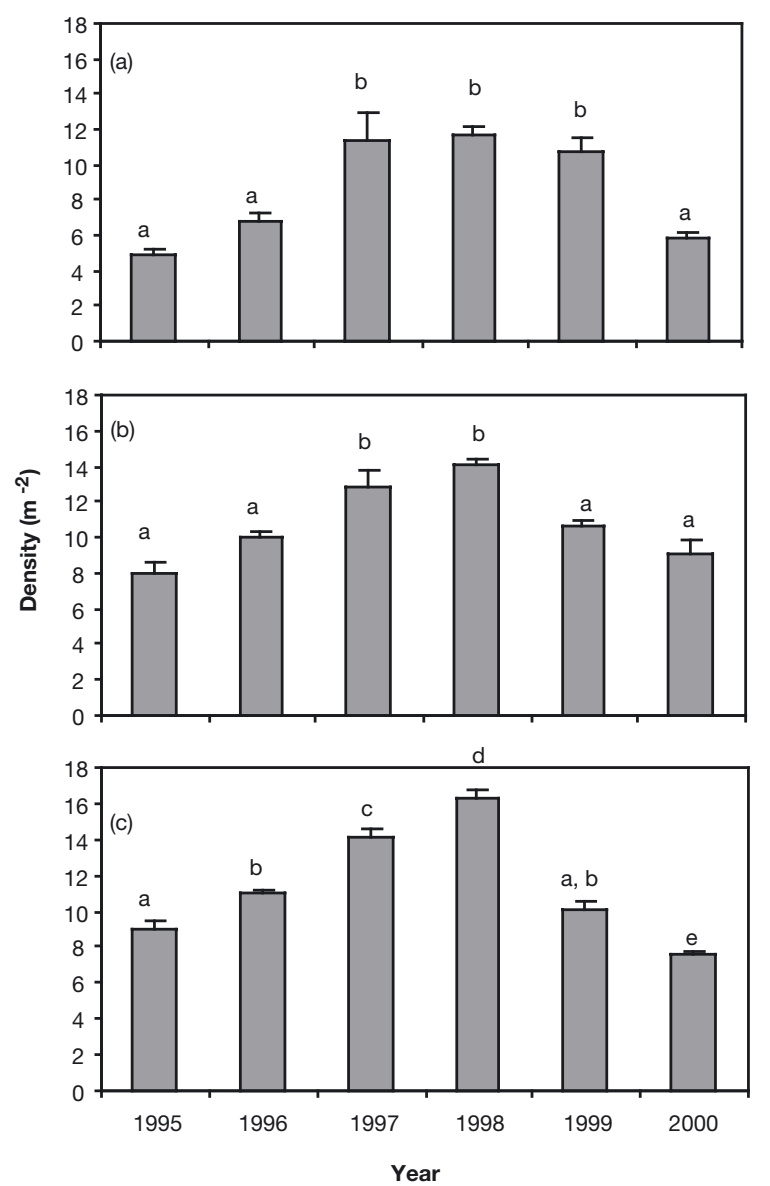

Fig. 2. Variation in density (mean $\pm \mathrm{SE}$ ) of all echinoderms over the survey period for 3 reef habitats: (a) emergent reef tops (ANOVA, $\left.F_{5,18}=14.26, \mathrm{p}<0.0001\right)$, (b) coastal reef walls $\left(F_{5,18}=14.67, \mathrm{p}<0.0001\right)$, (c) shallow-bank reefs $\left(F_{5,18}=82.13\right.$, $\mathrm{p}<0.0001)$. ANOVA measures between years; letters above histograms refer to significant groupings following pairwise SNK tests

resulting ordinations (Fig. 4) without any consistent sub-clustering by year or reef. Samples of the assemblage in 1998 are grouped with subsequent years, indicating the echinoderm assemblages for the 3 yr post-El Niño were more similar to each other than the 3 pre-El Niño years. Assemblages in post-El Niño years were significantly different from those of pre-El Niño years for all habitats (ANOSIM, minimum global $\mathrm{r}=0.892$, $\mathrm{p}<0.001$ ). The dissimilarities between pre- and post-El Niño assemblages were due to the complete disappearance of many species from all 3 habitats after 1997 (Table 1) rather than subtle changes in abundance. Interestingly, for the intertidal habitat (emergent reef tops), samples taken immediately pre-El Niño (1997) were separated from those of the first $2 \mathrm{yr}$ of the survey (Fig. 4a). Whilst 1997 samples still clustered overall with other pre-ENSO years (dendrogram not shown),
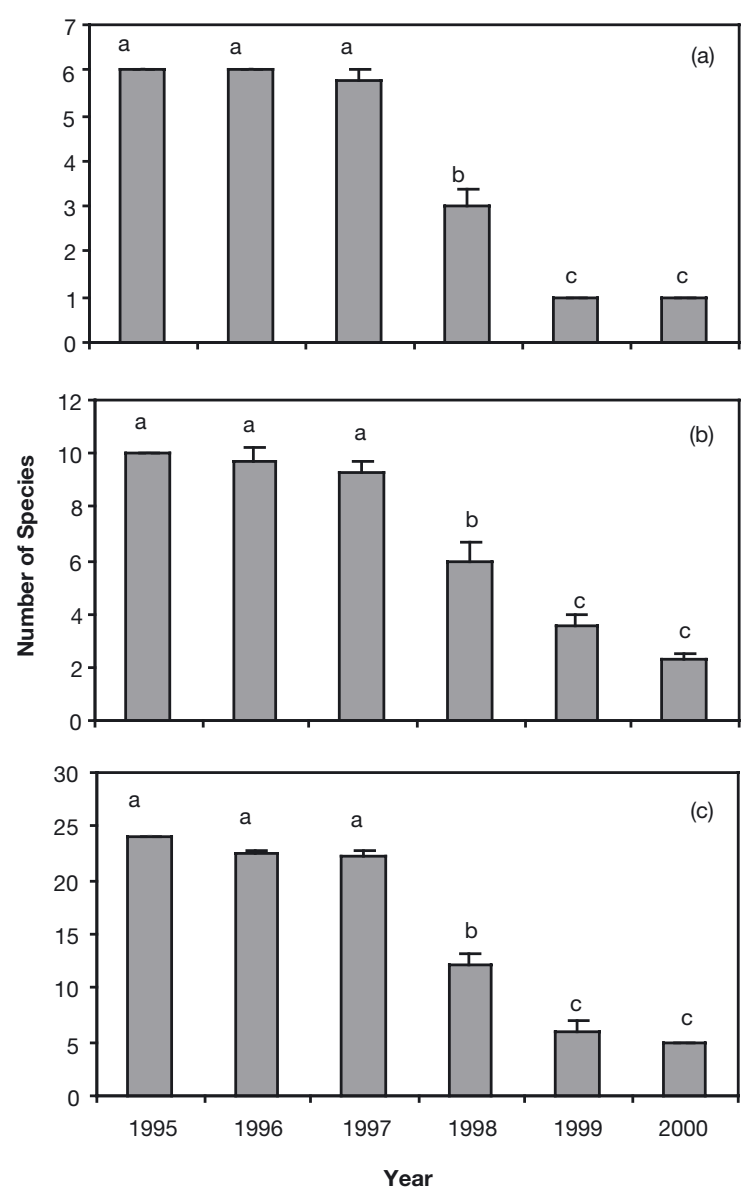

Fig. 3. Variation in number of echinoderm species (mean \pm $\mathrm{SE}$ ) over the survey period for 3 reef habitats: (a) emergent reef tops (ANOVA, $F_{5,18}=165.31, \mathrm{p}<0.0001$ ), (b) coastal reef walls $\left(F_{5,18}=62.14, \mathrm{p}<0.0001\right)$, (c) shallow-bank reefs $\left(F_{5,18}=\right.$ 222.00, $\mathrm{p}<0.0001)$. ANOVA measures between years; letters above histograms refer to significant groupings following SNK tests

the ordination suggests assemblage composition was changing prior to the onset of the major El Niño event.

Although all environmental parameters returned to pre-El Niño levels after 1998 (Fig. 1), the echinoderm assemblage composition did not demonstrate a return to pre-El Niño conditions over the survey. Therefore, as biotic and abiotic patterns were not consistent, further analysis to identify which environmental variables were best at explaining faunal patterns (i.e. BIOENV) was considered inappropriate.

\section{DISCUSSION}

The 1997-98 El Niño event had well-documented large-scale effects on coral reefs worldwide (Arthur 2000, Glynn et al. 2001, Guzman \& Cortes 2001, Var- 

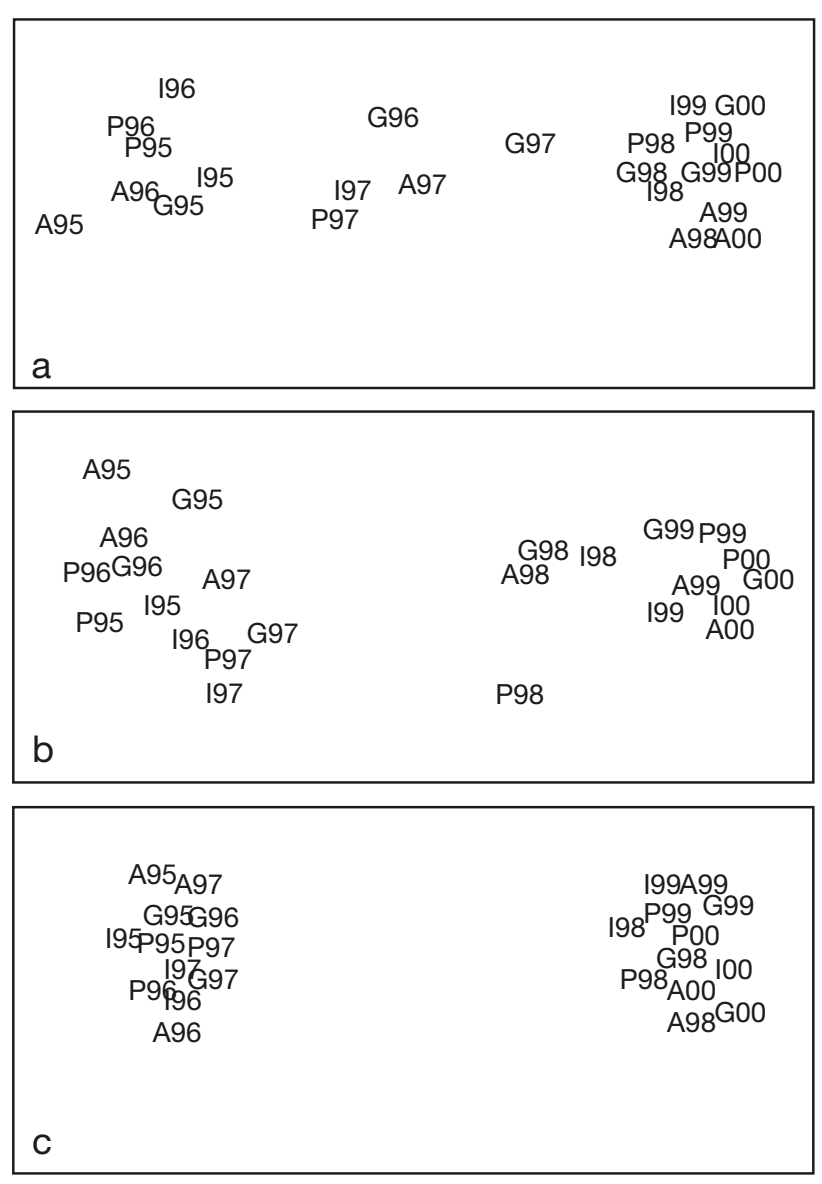

Fig. 4. MDS ordinations of the reef-associated echinoderm community data from northern Bahian reefs throughout the studied period. (a) Emergent reef top (stress: 0.02), (b) coastal reef walls (stress: 0.04) and (c) shallow-bank reefs (stress: 0.01). Codes: letters refer to replicate reef systems, numbers to year (1995-2000). All habitats demonstrate extensive shifts in assemblage composition over the 1998 El Niño period, distance between points on the ordinations reflecting how similar assemblages are to each other (closer points have a more similar composition)

gas-Angel et al. 2001). In Brazil, abiotic anomalies such as an abnormal (and prolonged) increase in sea-surface water temperature (Pezzi \& Cavalcanti 2001), reduced turbidity (Kelmo et al. 2003) and increased solar radiation (Conde et al. 2000) were recorded. Such variables, independently or combined, are able to cause several disturbances to coral-reef-associated organisms (Glynn 1990), and, therefore, it is reasonable to assume that the marked reductions in diversity, and changes in density, of the echinoderms from the reefs of northern Bahia were associated with the 199798 El Niño event.

The local extinction of 19 species of echinoderm from the study area demonstrates clearly that the 'stress' imposed during the 1997-98 El Niño (increased temperatures and solar radiation) had a dramatic effect on the assessed community. In subtidal regions, increased irradiation was enhanced by a decrease in turbidity, with the consequence of more UV light reaching the coral reefs (Kelmo et al. 2003). This combination of impacts was lethal to the majority of echinoderms in this region, including species inhabiting the emergent reef tops (naturally variable habitat receiving high levels of sunlight). Whilst the exact mechanisms behind the temperature and ultraviolet-lightinduced local extinction of such a large proportion of the reef echinoderm diversity remain unknown (and can only be speculated upon), present results highlight that El Niño events can impact dramatically important components of the reef beyond the actual corals themselves. Additionally, the disappearance of these species is clearly not a temporary phenomenon, as no recovery was evident $2 \mathrm{yr}$ after the El Niño event of 1997-98. This finding suggests that juvenile and larval echinoderms have not recruited successfully to the reefs over this post-El Niño period.

Such extinctions favoured the colonisation of the reef environment by opportunistic echinoids, particularly Diadema antillarum and, in the intertidal reefs, Echinometra lucunter. These echinoids did not suffer any apparent reduction in their density caused by the abnormally high seawater temperatures and increased solar radiation observed during the stress period (due perhaps to a nocturnal habit; Tuya et al. 2004). Conversely, their abundance increased to a high in 1998 and then returned to values similar to those recorded at the beginning of the study. Due to the comparatively rapid nature of their population increase, it is likely that the recorded density reflects migration of individuals from deeper water beyond the survey area (Glynn 1988) rather than actual population increases through increased larval recruitment; the urchins exploiting the reduced competition for grazing resources. Increases in urchin abundance have been noted elsewhere following bleaching events and the increase in algal cover on the reef (e.g. Haley \& Solandt 2001, Aronson et al. 2002). These opportunistic echinoids play an important role in reef conservation, as they graze the macroalgae that compete with the corals for space, resulting in successful recruitment of juvenile corals (Edmunds \& Carpenter 2001). They are important also in the carbon cycle and reef development as, while grazing, these echinoids remove a large proportion of calcium carbonate in addition to the growing algae. However, increased grazing has a negative effect on the reef, as it contributes significantly to reef bioerosion (Carreiro-Silva \& McClanahan 2001), leading to severe reef degradation. Therefore, the scale (and duration) of population increases in Diadema, for example, following such El Niño events may tip the 
balance between maintaining grazing pressure and the destruction of the reef framework. This indirect consequence of El Niño events has clear implications for the conservation and management of reef systems, and investigating why Diadema and Echinometra individuals were not as adversely affected by El Niño conditions is an area of future work highlighted by this study.

A further notable result of this study was the significant increase in urchin abundance in the survey prior to the onset of El Niño (1997). Additionally, for the emergent reef tops (the habitat which experiences the most stressful natural conditions), there was evidence of a change in assemblage composition in 1997, several months prior to the onset of El Niño. These results suggest that coral reef echinoderms were responding to environmental cues earlier than is generally considered to be the peak of El Niño. Reef impacts have been focussed primarily on the bleaching of corals which occurs once conditions have reached a certain critical level. Assessment of mobile organisms, such as echinoderms, may, therefore, potentially provide an 'early warning' of impending severe El Niño conditions, though clearly this response requires further investigation.

This study has demonstrated the first major impact of El Niño events on mobile coral-reef invertebrates. Echinoderms are important, often key, constituents of the reef ecosystem, and they are clearly highly vulnerable to the stresses associated with El Niño events. However, there is a highly differential impact evident from the Bahian reefs, with the majority of echinoderm species disappearing from the fauna, yet certain urchin species increasing their density. The impact is also long-lasting, with minimal recovery in diversity evident 2 yr after El Niño, so it is possible that groups of benthic organisms associated with reefs may be more vulnerable than the corals themselves. Therefore, it is important to include such vulnerable associated fauna in the assessment of El Niño events, not only for shortterm impacts but also in the longer term, as their presence/absence influences directly the fragile balance of coral-reef functioning. As El Niño events are predicted to become more frequent and severe (Timmermann et al. 1999), such assessments are particularly relevant.

\section{LITERATURE CITED}

Albuquerque MN, Guille A (1991) Ophiuroidea (Echinodermata) ao largo do Brasil: Banco dos Abrolhos, Cadeia submarina Vitoria-Trinidade e Plataforma Continetal adjacente. Bol Mus Nacion (Zool) 353:1-30

Alves OF, Cerqueira WRP (2000) Echinodermata das praias de Salvador (Bahia, Brasil). Rev Brasil Zool 17:543-553
Aronson RB, Precht WF, Toscano MA, Koltes KH (2002) The 1998 bleaching event and its aftermath on a coral reef in Belize. Mar Biol 141:435-447

Arthur R (2000) Coral bleaching and mortality in three Indian reef regions during an El Niño southern oscillation event. Curr Sci 79:1723-1729

Berkelmans R, Oliver JK (1999) Large-scale bleaching of corals on the Great Barrier Reef. Coral Reefs 18:55-60

Boeger WA, Kritsky DC (2002) Parasites, fossils and geologic history: historical biogeography of the South American freshwater croakers, Plagioscion spp. (Teleostei, Sciaenidae). Zool Scr 32:3-11

Booth DJ, Beretta GA (2002) Changes in a fish assemblage after a coral bleaching event. Mar Ecol Prog Ser 245:205-212

Carr MR (1996) Plymouth routines in multivariate analysis. Primer user manual. Natural Environment Research Council, Plymouth

Carreiro-Silva M, McClanahan TR (2001) Echinoid bioerosion and herbivory on Kenyan cora reefs: the role of protection from fishing. J Exp Mar Biol Ecol 262:133-153

Cerqueira WRP (1995) Sistematicae ecologia dos Ophiuroidea, Gray (1840) (Stelleroidea: Echinodermata) da Praia do Farol de Itapua, Salvador, Bahia, Brasil. Monografia de Bacharelado, Organismos Aquaticos. Universidade Federal de Bahia, Salvador

Clarke KR (1993) Non-parametric multivariate analysis of changes in community structure. Aust J Ecol 18:117-143

Clarke KR, Green RH (1988) Statistical design and analysis for a 'biological effects' study. Mar Ecol Prog Ser 46: $213-226$

Conde D, Aubriot L, Sommaruga R (2000) Changes in UV penetration associated with marine intrusions and freshwater discharge in a shallow coastal lagoon of the Southern Atlantic Ocean. Mar Ecol Prog Ser 207:19-31

Eakin CM (2001) A tale of two ENSO events: carbonate budgets and the influence of two warming disturbances and intervening variability, Uva Island, Panama. Bull Mar Sci 69:171-186

Edmunds PJ, Carpenter RC (2001) Recovery of Diadema antillarum reduced macroalgal cover and increases abundance of juvenile corals on a Caribbean reef. Proc Natl Acad Sci USA 98:5067-5071

Elliot JR, Jewson SP, Sutton RT (2001) The impact of the 1997/98 El Niño event on the Atlantic Ocean. J Climate 14:1069-1077

Feingold JS (2001) Responses of three coral communities to the 1997-98 El Niño Southern Oscillation: Galapagos Islands, Ecuador. Bull Mar Sci 69:61-77

Glynn PW (1988) El Niño warming, coral mortality and reef framework destruction by echinoid bioerosion in the eastern Pacific. Galaxea 7:129-160

Glynn PW (1990) Coral mortality and disturbances to coral reefs in the tropical eastern Pacific. In: Glynn PW (ed) Global ecological consequences of the 1982-83 El Niño Southern Oscillation. Elsevier, Amsterdam, p 55-126

Glynn PW, Matt JL, Baker AC, Calderon MO (2001) Coral bleaching and mortality in Panama and Ecuador during the 1997-1998 El Niño Southern Oscillation event: spatial/temporal patterns and comparison with the 1982-1983 event. Bull Mar Sci 69:79-109

Guzman HM, Cortes J (2001) Changes in reef community structure after fifteen years of natural disturbances in the Eastern Pacific (Costa Rica). Bull Mar Sci 69:133-149

Haley MP, Solandt JL (2001) Population fluctuations of the sea urchins Diadema antillarum and Tripneustes ventricosus at Discovery Bay, Jamaica: a case of biological succession? Caribb J Sci 37:239-245 
Kayanne H, Harii S, Ide Y, Akimoto F (2002) Recovery of coral populations after the 1998 bleaching on Shiraho Reef, in the southern Ryukyus, NW Pacific. Mar Ecol Prog Ser 239: 93-103

Kelmo F, Attrill MJ (2001) Cnidarian community structure of coastal reefs from northern Bahia, Brazil. Bull Mar Sci 69: $547-557$

Kelmo F, Attrill MJ, Jones MB (2003) Effects of the 1997-98 El Niño on the cnidarian community of a high turbidity coral reef system (northern Bahia, Brazil). Coral Reefs 22: 541-550

Kelmo F, Attrill MJ, Gomes, RCT, Jones MB (2004) El Niño induced local extinction of coral reef bryozoan species from northern Bahia, Brazil. Biol Conserv 118:609-617

Lindahl U, Öman MC, Schelten CK (2001) the 1997/1998 mass mortality of corals: effects on fish communities on a Tanzanian coral reef. Mar Pollut Bull 42:127-131

Linden O (1999) Coral mortality in the tropics: massive causes and effects. Ambio 27:588

Martin L, Suguio K (1992) Variations of coastal dynamics during the last 7000 years recorded in the beach-ridge plains associated with river mouths: example from the central Brazilian coast. Palaeogeogr Palaeoclim Palaeoecol 99: $119-140$

McClanahan TR, Muthiga NA, Mangi S (2001) Coral and algal changes after the 1998 coral bleaching: interaction with reef management and herbivores on Kenyan reefs. Coral Reefs 19:380-391

McPhaden MJ (1999a) El-Niño-the child prodigy of 1997-98. Nature 398:559-561

Editorial responsibility: Otto Kinne,

Oldendorf/Luhe, Germany
McPhaden MJ (1999b) Climate oscillations-genesis and evolution of the 1997-98 El-Niño. Science 283:950-954

Pezzi LP, Cavalcanti IFA (2001) The relative importance of ENSO and tropical Atlantic sea surface temperature anomalies for seasonal precipitation over South America: a numerical study. Clim Dyn 17:205-212

Santa-Isabel LM, Cerqueira WRP, Alves OFS (1996) Associação entre Phionereis reticulata (Say) (Ophiuroidea, Ophionereididae) e Malmgreniella variegata (Treadwell) (Polychaeta, Polynoidae) das Praias de Salvador, Bahia, Brasil. Rev Brasil Zool 13:137-142

Spalding MD, Jarvis GE (2002) The impact of the 1998 coral mortality on reef fish communities in the Seychelles. Mar Pollut Bull 44:309-321

Timmermann A, Oberhuber J, Bacher A, Esch M, Latif M, Roeckner E (1999) Increased El Niño frequency in a climate model forced by future greenhouse warming. Nature 398:694-697

Tommasi LR, Aron MA (1988) Equinodermes da plataforma continental Sueste do Estado da Bahia. Relatorios Internos Inst Oceanogr Univ São Paulo 19:1-6

Tuya F, Martin JA, Luque A (2004) Patterns of nocturnal movement of the long-spined sea urchin Diadema antillarum (Philippi) in Gran Canaria (the Canary Islands, central East Atlantic Ocean). Helgoland Mar Res 58: $26-31$

Vargas-Angel B, Zapata FA, Hernandez H, Jimenez JM (2001) Coral and coral reef responses to the 1997-98 El Niño event on the Pacific coast of Colombia. Bull Mar Sci 69:111-132

Submitted: July 14, 2003; Accepted: April 22, 2004

Proofs received from author(s): May 19, 2004 